\title{
Vzpomínání na Srpen: význam roku 1968 pro český exil v Rakousku a Švýcarsku
}

\section{Recalling August 1968: Significance of the year 1968 for the Czech Exile in Austria and Switzerland}

Ondřej Haváč / ondrej.havac@hotmail.com

Ústav pro soudobé dějiny AV ČR

\begin{abstract}
The Warsaw Pact invasion of Czechoslovakia caused thousands of people fleeing the country to the West. In spite of hard times at the beginning of the immigration, most of the refugees have been able to accommodate to the new conditions and build up a career and new life. This study deals with the Czech communities in Austria and Switzerland after 1968. The author uses the content analysis of the periodical press and recorded interviews to describe the Remembrance Culture of members of the communities. The main research question of the paper is whether the year 1968 (which is the milestone in the Czech history) plays any role in collective consciousness of the Czech exile.
\end{abstract}

\section{Keywords}

Prague Spring, Czech Exile, Culture of Remembrance, Collective Memory, Czech Exile Press 


\section{Úvod}

Málokteré datum představuje pro Čechy v jejich novodobých dějinách významnější mezník, než je 21. srpen 1968. K padesátému výročí invaze vojsk Varšavské smlouvy do Československa zveřejnila Česká televize průzkum, který vzbudil ve společnosti značný zájem. Vyplynulo z něj, že celá jedna třetina mladých neví, co se stalo 21. srpna $1968 .{ }^{1}$ Debata se následně stočila k výuce dějepisu na školách a neschopnosti jeho aktérů (učitelů, ředitelů či samotného ministerstva školství) se důsledněji věnovat moderním českým dějinám a vykládat je v patřičných souvislostech. Místo otázky po ne/oprávněnosti této kritiky se tento příspěvek věnuje jiné části zmíněného výzkumu, která již takovou pozornost nepřitáhla.

Oproti mládeži má naprostá většina těch, kteří se narodili před rokem 1968, nejen povědomí o srpnových událostech, ale považuje je zároveň za „obrovské historické národní trauma“, které by se mělo připomínat. ${ }^{2}$ Ostatně i tento rok proběhla celá řada vzpomínkových akcí a význam 21. srpna 1968 letos dokonce posvětila Poslanecká sněmovna, když schválila novelu zákona, která z tohoto data učinila Památný den obětí invaze a následné okupace vojsky Varšavské smlouvy. ${ }^{3}$ Jakým způsobem si ale připomínali srpnové události ti, kterým invaze vojsk Varšavské smlouvy do Československa změnila od základu život? Tato studie zaměřená na české krajanské komunity v Rakousku a Švýcarsku si klade za cíl zodpovědět, zda a jakým zpo̊sobem se v těchto komunitách připomínal 21. srpen 1968 a následná okupace. Lišila se nějakým zpo̊sobem tzv. vzpomínková kultura týkající se 21. srpna 1968 Čechů žijících v Rakousku a Švýcarsku před rokem 1989? A pokud ano, co to vypovídá o dané menšině a její sebe-identifikaci?

\section{Použité prameny, metody a literatura}

Výzkumná otázka tohoto př́íspěvku tedy zní: jakým zpơsobem si Češi v Rakousku a Švýcarsku připomínali srpnovou invazi? K jejímu zodpovězení vycházím z materiálů získaných během terénních výzkumů v Rakousku a Švýcarsku, které jsem uskutečnil v rámci zpracovávání dizertačního projektu: Komparace českého exilu v Rakousku a Švýcarsku po roce 1968. ${ }^{4}$ Ten byl věnován komparaci již zmíněných českých exilových skupin. Hlavní pramen v tomto případě představují nejvýznamnější periodika české krajanské obce v daných zemích, z nichž každé reprezentuje její jinou část. V případě české menšiny v Ra-

1 Odkaz 21. srpna 1968? Mladí lidé by se o něm měli učit v souvislostech/ ct24.ceskatelevize.cz https://ct24.ceskatelevize.cz/specialy/vyroci-invaze-v-srpnu-1968/2571766-odkaz-21-srpna-1968-mladi-lide-se-o-nem-meli-ucit-v, citováno 27. prosince 2019.

2 Průzkum pro ČT: Třetina mladých neví, co se stalo v srpnu 1968/ https://ct24.ceskatelevize.cz/domaci/ 2570581-pruzkum-pro-ct-tretina-mladych-nevi-co-se-stalo-v-srpnu-1968, citováno 27. prosince 2019.

3 Sněmovna schválila 21. srpen jako památný den obětí invaze/ https://www.lidovky.cz/domov/snemovna-schvalila-21-srpen-jako-pamatny-den-obeti-invaze, citováno 27. prosince 2019.

4 Haváč, Ondřej: Exil a identita. Komparace českého exilu v Rakousku a Švýcarsku po roce 1968. Dizertační práce, Brno 2018. Části příspěvku věnované popisu vývoje jednotlivých spolků byly převzaty právě z této práce. 
kousku se jedná o Videňské svobodné listy, Vídeňské menšinové listy (od roku 1972 vycházející pod názvem Krajanské noviny) a časopis Kulturního klubu Čechů a Slováki̊ v Rakousku. Krajané ve Švýcarsku, kteří byli sdružení ve Svazu československých spolků, ${ }^{5}$ vydávali od roku 1968 časopis Zpravodaj. Obsahová analýza těchto periodik a použitá komparativní metoda přinesla celou řadu zajímavých zjištění nejen o vztahu těchto skupin k událostem 21. srpna, ale v případě české menšiny v Rakousku i o vztahu mezi nimi samotnými.

Analyzovány byly především ta čísla a ročníky, u kterých byl předpoklad, že budou z velké části pojednávat o událostech 21. srpna. Obsahové analýze tak byla podrobena letní čísla uvedených periodik z let 1969 a 1970 a následně 1978 a 1988. Dva prvně zmíněné ročníky byly vybrány kvůli své časové blízkosti k srpnové invazi, a bylo tak možné detailně sledovat změnu př́stupu redakce daného periodika k situaci v Československu. Další dva ročníky, které představovaly kulaté výročí od vpádu vojsk Varšavské smlouvy, hrály klíčovou roli z hlediska vzpomínkové kultury českých krajanských spolků a organizací. Kolik prostoru danému tématu věnovaly a jazyk, jakým jej popisovaly, napověděly o daných skupinách mnohé.

V rámci rozboru pramenů přibyla k uvedeným tiskovinám i část materiálů ze spolkových archivů, které pojednávaly o aktivitách daného spolku v uvedených výročích, jako byly almanachy či nejrůznější tiskoviny. Jednalo se konkrétně o archiv Besedy Svatopluka Čecha, Besedy Slovan v Ženevě a archiv Výzkumného střediska historických menšin (Forschungszentrum für Historische Minderheiten), kde se nacházela část pramenů k vídeňským Čechům. ${ }^{6} \mathrm{~K}$ dokreslení celkového obrazu byla využita i metoda orální historie a část z orálně-historického materiálu, který byl získán během terénních výzkumů mezi krajany v daných zemích v letech 2011-2015, které byly uskutečněny v rámci již zmíněného dizertačního projektu. ${ }^{7}$

Z celé řady publikací věnovaných Čechům v Rakousku a obecně českému exilu druhé poloviny 20. století využívám v rakouském případě informace především z knih historiček Vlasty Valešové, Jany Starkové a rovněž z dvojjazyčného sborníku Vídeňšti Češi 1945-2005, který se skládá z příspěvků napsaných samotnými členy české menšiny. ${ }^{8}$ Důležité pro mě byly rovněž závěry historičky Margity Urbanek, ${ }^{9}$ která se obdobnou problematikou zabývala ve své dizertaci, a rovněž data obsažená v rozsáhlé sociologické studii

5 Dnes nese sdružení název Svaz spolků Čechů a Slováků ve Švýcarsku.

6 Archiv Forschungszentrum für historische Minderheiten ve Vídni (dále FZHM), fond Pozůstalost Karla Mataly; Archiv Besedy Svatopluka Čecha v Curychu. Almanach 1910 - 2010; Archiv Besedy Slovan v Ženevě. Přehled významnějších akcí.

7 Jednalo se o rozhovory: Soukromý archiv autora, rozhovor s Milanem Ráčkem. Sitzendorf / Schmida, 14. září 2011; Soukromý archiv autora, rozhovor s Přemyslem Janýrem, ml., Vídeň 15. září 2013.

8 Videňšti Češi 1945-2005. K dějinám národnostní menšiny/ Die Wiener Tschechen 1945-2005. Zur Geschichte einer Volksgruppe. Edd. H. Baslerová - M. Brandeisová - J. Kroupa - J. Starková. Wien - Praha 2006; Doma v cizině. Češi ve Vídni ve 20. století. / Zu Hause in der Fremde. Tschechen in Wien im 20. Jahrhundert. Ed. V. Valešová. Praha 2002.

9 Margita Urbanek (*1954) přišla jako desetiletá spolu s rodinou do Rakouska v posrpnové emigrační vlně. Studovala nejprve oděvní průmyslovou školu (Textilhandelsakademie) ve Vídni a koncem sedmdesátých let započala studium Sociologie na Vídeňské univerzitě a dlouhodobě se věnovala právě tématu českých uprchlíků v Rakousku. Doktorský titul získala za práci: Urbanek, Margita: Tschechische Flucht - und Arbeitsmigranten in Österreich. Wien 2009. 
Integrationsprobleme der Ostblockflüchtlinge in Österreich, kterou v roce 1988 pro rakouské ministerstvo vnitra zpracovala doktorka Mlynářová-Dubská. ${ }^{10}$

Při analýze pramenů týkajících se krajanské komunity ve Švýcarsku navazuji na práci kolegů z Univerzity Palackého v Olomouci a na publikace Centra pro československá exilová studia, jako jsou například: Československý exil a krajanská hnutí ve Švýcarsku v letech 1945-1989 nebo Emigrace: Sbornik historických praci Centra pro československá exilová studia. ${ }^{11} \mathrm{Z}$ literatury, která byla vydána k danému tématu ve Švýcarsku, jsem čerpal informace především ze sborníku Zuflucht Schweiz. Der Umgang mit Asylproblemen im 19. und 20. Jahrhundert a knihy Exil in Basel, která představuje sbírku rozhovorů s Čechy a Slováky ve Švýcarsku vedených spisovatelem a žurnalistou Dušanem Šimkem. ${ }^{12}$

\section{Vzpomínková kultura (Kultura, pamět' a vzpomínky)}

K odpovědi na klíčovou otázku tohoto příspěvku: Co znamenal 21. srpen pro Čechy v exilu a jak si jej pripomínali, je potřeba alespoň ve stručnosti představit teoretické koncepty, které stojí v pozadí tzv. vzpomínkové kultury (Culture of Remembrance, Erinnerungskultur). V ní se prolínají témata související s pojmy kolektivní a kulturní paměti, skupinové identity i procesu vzpomínání. ${ }^{13}$ Stěžejními publikacemi byly v tomto ohledu práce „otců zakladatelů“ pamětových studií Maurice Halbwachse, Jana a Aleidy Assmannových nebo Pierra Nory. ${ }^{14}$ Podle nich je pamět neodlučitelně vázána k sociální skupině. Manželé Assmanovi navázali na Halbwachsovu teorii sociální podmíněnosti lidské paměti a soustředili se při popisu staroorientálních kultur na souvislost mezi utvářením identity skupiny a jejím vztahem $\mathrm{k}$ minulosti.

Podle Jana Assmanna představuje vzpomínková kultura sdílené vědomí o společné minulosti dané skupiny. Nicméně minulost se v kolektivní paměti neuchovává „jako taková, nýbrž je soustavně reorganizována proměňujicími se referenčními rámci postupujici př́tomnos-

10 Mlynář-Dubská, Irena: Integrationsprobleme der Ostblockflüchtlinge in Österreich. Wien 1988.

11 Emigrace. Sborník historických prací Centra pro československá exilová studia. Edd. K. Konečný - T. Motlíček. Olomouc 2006; Studie z dějin emigrace. Sborník studentských prací. Edd. K. Konečný - T. Motlíček. Olomouc 2003; Trapl, Miloš - Skoupý, Arnošt - Kouřil, Miloš: Československý exil a krajanská hnutí ve Švýcarsku v letech 1945-1989. Od května 1945 do srpna 1968. Olomouc 2004.

12 Šimko, Dušan: Exil in Basel. Gespräche mit Flüchtlingen aus der Tschechoslowakei. Košice 2003.

13 Srov. Krauss, Marita - Scholl-Schneider, Peter: Odchody a návraty. Vzpomínková kultura a životní příběhy sudetských Němců v českých zemích a Bavorsku ve 20. století. Praha: Antikomplex 2015 nebo Nekula, Marek: Smrt a zmrtvýchustáni národa: Sen o Slavíně v české literatuře a kultuře. Praha: Karolinum 2017. K definici pojmu (kulturní, kolektivní) paměti srov. Tuček, Jan: Pamět. In: Lucie Štorchová a kol.: Koncepty a dějiny. Proměny pojmů v současné historické vědě. Praha 2014, s. 244-257.

14 Halbwachs, Maurice: Kolektivni pamět. Praha 2010; Assmann, Jan: Kultura a pamět. Písmo, vzpomínka a politická identita rozvinutých kulturách starověku. Praha 2001; Nora, Pierre: Between Memory and History. Les Lieux de Mémoire. In: Representations, č. 26, Oakland 1989, s. 7-24. Dostupné z: https://www.jstor.org/ stable/2928520?seq=1\#page_scan_tab_contents, citováno 1. února 2017. Česky: Nora, Pierre: Mezi pamět a historii. Problematika míst. In: Cahiers du CEFRES, č. 10, Praha 2010. Dostupné z: http://www.cefres. cz/IMG/pdf/nora_1996_mezi_pameti_historii.pdf, citováno 1. února 2017. 
$t i$ “. ${ }^{5}$ Jinými slovy jde vždy o vnímání minulosti a historických událostí důležitých pro danou skupinu z aktuální perspektivy, a o „zpřítomňování“ a udržování těchto historických mezníků v jejím kolektivním vědomí. Právě ono zpřítomňování historických událostí, osobností nebo míst, se odehrává prostřednictvím kolektivního procesu vzpomínání. Ten nabývá u společenství mnoha rozdílných forem. Ke vzpomínkové kultuře tak patří nejenom oslavy státních svátků a výstavba památníků, ale například i rekonstruování slavných bitev či účast na náboženských rituálech. Jakým zpơsobem si pak skupina historickou událost připomíná (nebo se na ni naopak snaží zapomenout a vytěsnit ji z kolektivní paměti), vypovídá mnohé o její sebeidentifikaci. České krajanské a exilové skupiny nebyly výjimkou.

\section{1. srpen a Češi v zahraničí}

Právě 21. srpen 1968 ovlivnil české krajanské a exilové organizace zásadní měrou. Od poloviny 60. let již nebyla železná opona obklopující československé území tak nepropustná. ${ }^{16}$ Pamětníci žijící tou dobou v západních zemích vzpomínali, že bylo najednou možno v ulicích jejich města zahlédnout rodinné auto s československou poznávací značkou nebo zaslechnout češtinu na kampusu místní univerzity. ${ }^{17}$ Radě krajanů se otevřela možnost po letech navštívit svoji bývalou vlast. ${ }^{18}$ Pražské jaro si svobodu cestování vepsalo do svého „akčního programu“. Ovšem invaze 21. srpna 1968 a následný politický vývoj ukončily naděje, které mnozí vkládali do reformního procesu. Zklamání ze zmařených očekávání bylo obrovské a míra deziluze byla přímo úměrná velikosti uprchlické vlny směřující do svobodného světa, ${ }^{19}$ kde zásadně ovlivnila tamní krajanské komunity.

Naproti tomu došlo bezprostředně po invazi v mnoha západních zemích ke vzepětí solidarity s okupovaným Československem a místní vlády začaly poskytovat všemožnou pomoc československým uprchlíkům. Do práce se ihned zapojily i krajanské organizace

15 Assmann, J. Kultura a pamět, s. 42.

$16 \mathrm{~K}$ uvolnění přísného režimu v oblasti cestovního ruchu z 50. let došlo po zasedání ÚV KSČ z prosince roku 1963, kdy se cestování - především do zemí socialistického tábora - mělo stát normální záležitostí těch občanů, kteří si „řádně plní svoje pracovní úkoly a aktivně se zapojují do veřejného a politického života, a s jejich výjezdem souhlasí závodní nebo místní orgány“. Viz Rychlík, Jan: Cestováni do ciziny v habsburské monarchii a v Československu. Pasová, vízová a vystěhovalecká politika 1848-1989. Praha 2007, s. 65 .

17 V rámci rozhovoru vzpomínala na pražské jaro například Ilona Mühlbergerová (rozená Žmolová), která přišla do Rakouska s rodinou v roce 1956. Viz: Soukromý archiv autora, rozhovor s Ilonou Mühlbergerovou, Steinergasse 7, Vídeň 19. září 2013.

18 Do Československa se v roce 1968 vrátila například Hana Sládková-Koželuhová, která zde zažila i následnou invazi vojsk Varšavské smlouvy. Viz: Soukromý archiv autora, rozhovor s Hanou Sládkovou-Koželuhovou, Ženeva, Švýcarsko 16. srpna 2014.

19 O zklamání z potlačení pražského jara jako o jednom z hlavních motivů pro emigraci čs. občanů se zmiňuje např.: Kusin, V. Vladimir: From Dubcek to Charter 77. A study of 'normalization 'in Czechoslovakia 1968 1978, Edinburgh 1978, s. 171 nebo studie Banki, Christine - Späti, Christopher: Ungaren, Tibeter, Tschechen und Slowaken. Bedingungen ihrer Akzeptanz in der Schweiz der Nachkriegszeit. In: Zuflucht Schweiz. Der Umgang mit Asylproblemen im 19. und 20. Jahrhundert. Die Schweiz und der Osten Europas. Edd. C. Goehrke - W. G.Zimmermann. Zürich 1994, s. 393. 
daných zemí a finančně i materiálně podporovaly nově př́íchozí, mnohdy v naději, že tito rozšîrí členskou základnu českých spolkủ. Nicméně po odeznění prvotní euforie následovala ne vždy bezproblémová „denní rutina“. Značná část československých uprchlíků se soustř̌edila na co nejrychlejší začlenění do místní společnosti, získání odpovídajícího zaměstnání a zázemí. Spolková činnost byla těmto lidem cizí, což vyvolávalo ve vztazích mezi krajany a posrpnovými exulanty stále nové třecí plochy a vzájemně to české skupiny v zahraničí odcizovalo. Tito lidé chtěli často zapomenout, co měli za sebou. ${ }^{20}$ Mohla se tedy vůbec rozvinout tzv. vzpomínková kultura okolo data, které sice ovlivnilo životy mnoha osob, ale které chtěl velký počet $\mathrm{z}$ nich co nejdřive vytěsnit? Co a proč by si krajané měli 21. srpna připomínat?

\section{1. srpen a Češi v Rakousku}

$\mathrm{V}$ př́padě české menšiny v Rakousku je důležité nejen co a proč, ale také $k d o$ (respektive která skupina) si dané výročí připomínal. O Češích v Rakousku, a především ve Vídni, pojednává celá řada publikací, ${ }^{11}$ a proto se zde omezím jen na popis základního kontextu důležitého pro následnou analýzu pramenů. Především: tamější česká menšina byla rozdělena. Zásadní zlom nastal s únorovým převratem v Československu, který nutil členy české menšiny zaujmout k vývoji ve vlasti souhlasný nebo odmítavý postoj. Nové komunistické vedení rovněž usilovalo o získání Čechů v Rakousku na svou stranu prostřednictvím Československého ústavu zahraničního, čímž ale významně zvyšovalo v celé menšině napětí. Postupem času tak vznikly dva znepřátelené tábory s vlastní sítí spolků a novinami. ${ }^{22}$ V květnu 1948 byly ve Vídni založeny Vídeňské menšinové listy, které se staly hlavním tiskovým orgánem hájícím kroky nového československého vedení. V následujícím roce vzniklo Sdruženi Čechi̊ a Slováků v Rakousku, které zaujalo vedoucí pozici mezi menšinovými spolky s kladným postojem k Československu. Díky výhodám, které nabízelo, a podpoře pražského vedení, se brzy vyvinulo v organizaci, která měla v roce 1952 přibližně 5000 členů ve 24 pobočkách nejenom ve Vídni, ale i ve Štýrském Hradci (Graz), Linzi, Wiener Neustadtu a Berndorfu. Vliv tak mělo podle odhadů na zhruba třetinu české menšiny. ${ }^{23}$

20 Srov. Mlynář-Dubská, I.: Integrationsprobleme, s. 109.

21 Např.: Tschechen in Wien. Zwischen nationaler Selbstbehauptung und Assimilation. Ed. R. Wonisch. Wien 2010. Nebo Doma v cizině. Češi ve Vídni ve 20. století. / Zu Hause in der Fremde. Tschechen in Wien im 20. Jahrhundert. Ed. V. Valešová. Praha 2002; Tschechen und Österreicher. Gemeinsame Geschichte, gemeinsame Zukunft. Ed. T. Knoz. Brno 2006.

22 Rovněž velký počet osob stál mimo oba tábory. Odhaduje se, že tvořili 30 až $40 \%$ české menšiny v Rakousku. Více o formování menšiny po roce 1945 v knize: Valešová, Vlasta: Videňšsti Češi včera a dnes. Úvod do dějin a současnosti české národnostní skupiny ve Vídni. /Die Wiener Tschechen einst und jetzt. Eine Einführung in Geschichte und Gegenwart der tschechischen Volksgruppe in Wien. Praha 2004, s. 113-119.

23 Valešová, V.: Vídeňšti Češi včera a dnes, s. 115. Mezi výhody patř̌ilo snadněǰ̌ś získání víz či možnost se zúčastnit hromadných zájezdů do českých měst, rekreačních pobytů nebo dětských táborů v Československu. Do Vídně byly zvány české divadelní soubory, populární zpěváci či herci. Postupně se ke Sdruženi přidaly spolky jako Vlastenecká omladina, Národni dům, Klub československých turistĩ, SK Slovan a především Školský spolek Komenský ve Vidni, čímž se místní české školství ocitlo pod dohledem komunistického režimu. 
V reakci na vznik a aktivity prorežimního Sdruženi Čechů a Slováků v Rakousku se brzy začal sjednocovat i protirežimní proud, jehož předním tiskovým orgánem, tvrdě kritizujícím nové poměry v Československu a pražský režim, byly Videňské svobodné listy. Mezi hlavní představitele této skupiny patřil sociální demokrat a člen vídeňského zastupitelstva Josef Jírava. V roce 1951 byla obnovena Menšinová rada české a slovenské větve v Rakousku jako střechová organizace, která pod sebou sdružovala spolky, které odmítaly spolupracovat s komunistickým režimem v Československu. ${ }^{24} \mathrm{Na}$ počátku padesátých let se rovněž rozštěpila i organizace místního Sokola. ${ }^{25}$

Pražské jaro pak vneslo novou dynamiku do vzájemných vztahů. Obě skupiny jej sledovaly s nadějemi, očekáváními i obavami. Např́klad ve Vídeňských svobodných listech vyšel 2. srpna 1968 na přední straně obsáhlý článek: Svět hledí k Praze - konference v Čierne nad Tisou, který obsáhle pojednával o jednáních československých a sovětských komunistů. ${ }^{26}$ Hned vedle něj byl komentář Josefa Jonáše: Protestujeme!, ve kterém popisoval a zároveň obhajoval změny v zemi těmito slovy: „Je to jedinečný a statečný pokus o obrodu komunismu, o novou cestu komunistické diktatury. [...] V̌sechny ty měsice letošního roku, po které se zatajeným dechem sledujeme tento vývoj, jsou jedinečným vysvědčením politické, ba státnické moudrosti československého lidu. "27

O to větší rozhořčení vyvolal vpád vojsk Varšavské smlouvy na území Československa v noci na 21. srpna 1968, kdy i prorežimní Vídeňské menšinové listy na úvodní straně otiskly dva dny po invazi článek nazvaný: Vratte ČSSR nezávislost!, který začíná slovy: „Je to neuvěritelné, ale stalo se skutkem. " 28 Oba tábory rozdělené menšiny se okamžitě zapojily do pomoci přicházejícím uprchlíkům z Československa, kterých bylo hned v prvních dnech po invazi v Rakousku neuvěřitelných $162000 .{ }^{29}$ Značná část z nich se sice brzy vrátila do vlasti, nicméně proud uprchlíků nepřestával až do 9 . ř́ína roku 1969. ${ }^{30}$ Bylo to právě

24 Patřily sem spolky jako České srdce, Jednota Máj, Dělnická tělovýchovná jednota (DTJ) nebo Akademický spolek ve Vidni.

25 Vše vyvrcholilo na mimořádné valné hromadě Sokolské župy rakouské v roce 1952 konající se v Národním domě, kde se po bouřlivém jednání odtrhly od Sokolské župy rakouské jednoty Sokola I-V a X, jejichž zástupci valnou hromadu opustili a přidali se ke Sdruženi Čechů a Slováků. Ve Vídni tak de facto vznikly dvě sokolské organizace, jejichž členové - až na výjimky - s druhou „nepřátelskou“ skupinou nekomunikovali a kontakty udržovali jen v rámci své střechové organizace. Srov. Valešová, V.: Vídeňšti Češi včera a dnes, s. 115.

26 Svět hledík Praze - konference v Čierne nad Tisou. Vídeňské svobodné listy, 2. srpna 1968, č. 31/32, s. 1.

27 Jonáš, Josef: Protestujeme! Vídeňské svobodné listy, 2. srpna 1968, č. 31/32, s. 1.

28 Vratte ČSSR nezávislost! Vídeňské menšinové listy, 23. srpna 1968, č. 35, s. 1.

29 Starek, Jana: Česká menšina a československý exil po roce 1968 ve Vídni. In: Vídeňští Češi 1945-2005. K dějinám národnostní menšiny/ Die Wiener Tschechen 1945-2005. Zur Geschichte einer Volksgruppe. Edd. H. Basler - M. Brandeis - J. Kroupa - J. Starek. Wien - Praha 2006, s. 302. Podle statistik Státní bezpečnosti se zdržoval největší počet posrpnových uprchlíků ve Švýcarsku (13000 osob), následně v Kanadě (12 000), v Rakousku (10 000), ve Spolkové republice Německo (9 000). Podle předběžných odhadů analytického odboru II. správy FS ZS z 26. května 1970 se k tomuto dni zdržovalo v zahraničí 67873 československých občanů, z čehož 11853 pocházelo ze Slovenska. Srov. Bumová, Ivica: Postoj ŠtB k emigrácii československých občanov v rokoch 1963-1983 (s dôrazom na Západoslovenský kraj). In: E/migrácie a Slovensko. Diverzita ako faktor transformácií identít. Ed. D. Luther. Bratislava 2006, s. 42.

30 Uzavření hranic se uskutečnilo na základě společné vyhlášky ministerstva vnitra a ministerstva zahraničních věcí, která upravovala platnost výjezdních doložek (č. 115/1969 Sb.) Její celé znění viz: Předpis 
Rakousko, které neslo na svých bedrech nápor této uprchlické krize stejně jako v případě mad’arského povstání o 12 let dříve. Česká menšina byla všemožně nápomocná. ${ }^{31}$

Redakce obou českých periodik začaly sloužit jako informační a poradenská střediska, kde se uprchlíci dovídali vše potřebné o hostitelské zemi a místech, kde bylo možné získat materiální nebo finanční pomoc. Zástupci menšiny radili také v otázkách získání dokumentů potřebných $\mathrm{k}$ pobytu, popřípadě k vycestování do dalších zemí. I rakouský rozhlas vysílal řadu oznámení pro uprchlíky v češtině, rovněž za spolupráce se zástupci české menšiny. Pomoc nabízeli jak jednotlivci, tak i celé krajanské spolky. Do roku 1970 si tak Rakousko za svou cílovou zemi zvolilo více než 11000 posrpnových uprchlíků. Nejprve byli příchozí z Československa, tedy ti kteří se rozhodli zůstat v Rakousku ${ }^{32}$ a požádali o azyl, vítáni. Řada spolků si od nich slibovala omlazení a „novou krev“ pro svoji členskou základnu. Většinou se totiž jednalo o mladé, vzdělané lidi do 30 let, studenty nebo rodiny s jedním či dvěma dětmi. Byli mezi nimi umělci, vědci i prominentní politici pražského jara, které k opuštění vlasti donutila počínající normalizace. ${ }^{33}$

Brzy se ovšem ukázalo, že vzájemné soužití bude komplikované. Na zhoršujících se vztazích se přitom podílela celá řada faktorů. Pro posrpnové uprchlíky se jednalo o nepříliš přehledné prostředí. Podle slov narátorů nechtěli mít nově příchozí nic společného s prorežimními spolky, ani nebyli schopni nalézt společnou řeč s protirežimním proudem stojícím na tradicích první republiky, kterou zažil z posrpnových uprchlíků jen málokdo. $\mathrm{Z}$ těchto důvodů se tito lidé snažili po příchodu do Rakouska především co nejdříve začlenit do většinové společnosti. Jana Stárková vidí příčiny vzájemného neporozumění jak v generačním rozdílu, tak i výchovou a vzděláním formovaném odlišném vidění světa, se kterým Češi a Slováci mladší generace přicházeli do Rakouska. ${ }^{34}$ Tato situace počátkem

115/1969 Sb. In: Poslanecká sněmovna Parlamentu České republiky. Sbírka zákonů. Dostupné z: https:// www.psp.cz/sqw/sbirka.sqw?cz=115\&r=1969, citováno 18. dubna 2017.

31 Stejně jako v případě mad’arské uprchlické vlny i nyní se rakouské úřady ve spolupráci s UNHCR a ICEM snažily ty, kteří se rozhodli pro trvalý odchod ze země, co nejrychleji přepravit z Rakouska do vybraných hostitelských zemí. Do akce se zapojily vlády demokratických států - Švýcarska, Spolkové republiky Německo, Francie, Spojeného království, Kanady, Belgie, Švédska, USA, Austrálie či JAR. V době ekonomické konjuktury byl na Západě velký zájem o kvalifikovanou pracovní sílu, a tak do rakouských uprchlických táborů směřovali nejen zástupci vlád, ale i př́mo zástupci firem. Srov. Stern, Silke: Die tschechoslowakische Emigration. Österreich als Erstaufnahme- und Asylland. In: Prager Frühling. Das internationale Krisenjahr 1968. Edd. S. Karner - N. Tomilina a kol. Köln 2008, s. 1038.

32 Naprostá většina nově příchozích přitom volila ke svému životu rakouské hlavní město. Podle výsledků sčítání lidu z roku 1981, které zveřejnil Rakouský statistický úřad, se k české obcovací řeči přihlásilo pouze 5168 rakouských občanů, z čehož jich žilo ve Vídni 4 057. Srov. Archiv FZHM, fond Pozůstalost Karla Mataly r. č. 27/1125. Wohnbevölkerung 1981mit österreichischer Staatsbürgerschaft nach ausgewählten Umgangssprachen und Bundesländern.

33 Rakousko a Vídeň si za svůj domov (byt̉ někdy kvůli svému povolání jen jako přechodný) zvolili lidé jako dirigent Martin Turnovský, Přemysl Janýr, divadelní herečka Renáta Olárová, režisér Vojtěch Jasný a mnoho dalších v zahraničí žádaných odborníků.

34 Např́iklad Starek, Jana: Česká menšina a československý exil po roce 1968 ve Vídni, s. 195-208. Historička Jana Stárková, narozená v roce 1954 v Berlíně, uznávaná překladatelka, publicistka a historička, spoluzakladatelka Mezinárodni helsinské federace pro lidská práva. Dlouhodobě se věnuje kromě židovské problematiky také české menšině ve Vídni a obecně česko-rakouským vztahům v 19. a 20. století. Působila také řadu let na univerzitách v Brně, Praze a Vídni, podílela se na vzniku Výzkumného střediska pro historické menšiny 
70. let vyústila v založení nových spolků posrpnového exilu, mezi nimiž vynikal Kulturní klub Čechi̊ a Slovákư v Rakousku. Především do těchto sdružení posrpnového exilu si následně našli cestu signatáři Charty 77, kteří získali v Rakousku politický azyl. Rozpory mezi jednotlivými skupinami přetrvaly až do pádu železné opony a společnou instituci Poradni sbor pro českou národnostni menšinu, který měl sdružovat jednotlivé spolky, se podařilo založit až v roce 1994. Tyto všechny faktory se projevily na formování vzpomínkové kultury jednotlivých proudů uvnitř české menšiny.

\section{Mezník zapomínaný?}

Začneme-li analýzou Videňských menšinových listů, tedy hlavního tiskového orgánu prorežimní části menšiny, představoval 21. srpen 1968 datum jednoznačně „zapomínané“, respektive datum, o kterém se nepsalo. I přes počáteční kritiku a odsouzení invaze vojsk Varšavské smlouvy do Československa, která byla označena za „okupaci staré vlasti“, ${ }^{35}$ docházelo v redakci postupně k přebírání oficiálního výkladu událostí. Po zbytek roku 1968 se články v dalších číslech Videňských menšinových listů omezovaly spíše na popis probíhajících událostí bez zásadnějších komentárưu, popřípadě reagovaly na kritiku protirežimního proudu jako například v článku: Hysterické štvani v těžkých chvilich, ve kterém redaktoři citovali francouzského filozofa Blocha: „Kdo mlč $k$ Vietnamu, nemá právo soudit o Československu!"36

S postupem času byl stále patrnější př́iklon redakce a vůbec celého Sdružení Čechů a Slováků v Rakousku k formujícímu se normalizačnímu vedení v čele s Gustávem Husákem, i když ještě v ř́ijnu 1968 v souvislosti s druhou moskevskou návštěvou Alexandera Dubčeka psaly noviny o naději, že „se podař́ všechny dočasné problémy vyřě̌it a pokračovat na cestě $k$ socialismu s lidskou tvấri ${ }^{\text {“ }}{ }^{37}$ Od října začaly v novinách také vycházet oficiální stanoviska zástupců ČSSR, jako byl projev vyslance Pavla Novotného k 50. výročí vzniku Československa. Bylo to ostatně téma vzniku republiky, kterému byla na stránkách listů věnována každý rok dostatečná pozornost spolu s jubilei k založení Školského spolku Komenský a prvnímu máji.

V roce 1972 byly listy přejmenovány na Krajanské noviny nesoucí podtitul Časopis pro prátelství, svébytnost a svornost. $\mathrm{V}$ té době $\mathrm{v}$ nich již převažovaly články o nekonfliktních tématech typu zájezdů krajanů do Československa, které „patři $k$ nejoblíbenějš́m událostem $v$ krajanském životě vuibec", 38 nebo rozebíraly stavbu pražského metra či otevření nového bratislavského mostu. Název Pražské jaro se objevoval pouze jako označení pro hudební

(Forschungszentrum für historische Minderheiten) a v současnosti působí ve Vídeňském Wiesenthalově institutu pro studium holokaustu.

Vratte ČSSR nezávislost! Vídeňské menšinové listy, č. 35, 23. srpna 1968, s. 1.

36 Článek dále pokračuje: „A to si pane Jonáši zapište za uši! Váš postoj viǔci neprávu na světě je vždy zastřen jedinou barvou a to je vaše barva politická. "Srov. Hysterické štvani v těžkých chvilich. Vídeňské menšinové listy, č. 38, 12. záŕí 1968, s. 1.

37 Podruhév Moskvě. Vídeňské menšinové listy, č. 42, 10. ř́ijna 1968, s. 1.

38 Plná náruč jubileí. Krajanské noviny, č. 1, 30. března 1972, s. 1. 
festival. K 10. výročí invaze vojsk Varšavské smlouvy byl v Krajanských novinách otištěn článek: Jak to bylo v srpnu před deseti lety, který byl již věrnou kopií názorů sovětského i pražského normalizačního vedení na „krizové obdobi v Československu“, během kterého byl socialismus ohrožen „světovými reakčnimi silami a jejich taktikou podkopávání zevnitř.“ Okupace Československa se proměnila na „včasnou mezinárodni pomoc [...] $k$ zabráněni agrese a revanšismu imperialistických sil [...]“, které měly usilovat „o porážku moci dělnické tř́dy “. ${ }^{39}$ Dále následovalo ujištění, že základní lidská práva jsou v ČSSR dodržována. Pro tuto část menšiny byl 21. srpen 1968 neštastnou událostí, která se sice nemohla odestát, ale nemusela se často připomínat. A pokud ano, tak jen jako „poučení z krizového vývoje“.

\section{Srpen varuje!}

Pro protirežimní tábor Čechů v Rakousku byl naopak 21. srpen velmi důležitým datem. Již první vydání novin, které vyšlo po invazi, začínalo nadpisem: Československo spoutáno imperialismem $S S S R^{40} \mathrm{~s}$ velkou fotografií pietního místa, kde byla během invaze zastřelena sedmnáctiletá dívka. Hned pod článkem byla výzva ke společnému protestu, který byl svolán Menšinovou radou české a slovenské větve v Rakousku na 31. srpna 1968. V následujících číslech představovalo dění v Československu hlavní obsahovou stránku novin. Listy rovněž přinášely vyjádření členů rakouské vlády a parlamentu k událostem v sousední zemi.

Brzy se ovšem projevily s novou intenzitou tradiční konflikty mezi jednotlivými znepřátelenými částmi české menšiny. Už v září 1968, v reakci na článek prorežimních Videňských menšinových listi̊, uvádí Josef Jonáš v článku Moskva a my: „Zbaběle mlčet, dívat se na znásilňováni lidu, čekat až jak to dopadne a potom se přidat na stranu vítěze, přidat se na stranu toho, kdo naši vlast a národ niči a znásilňuje, kdo lidu bere i ten kousek svobody, který si posledni týdny vybojoval! Ani stopy studu nad doporučováním tohoto bezcharakterního postoje. Ani kousek hanby nad tím, že naše krajany navádi ,Menšinové listy" ke zradě vlastního lidu. "41 Menšinové listy a celá prorežimní skupina české menšiny byly za své postoje kritizováni a označováni za zrádce, kteří svým „zamlčováním“ skutečných událostí dělají vlasti medvědí službu, která se rovná vlastizradě.

Videňské svobodné listy (VSL) pak věnovaly událostem v Československu velkou pozornost i v následujícím roce. Přední stránky novin plnily zprávy o odvolání Smrkovského, sebeupálení Jana Palacha a o nastupujícím ostrém kurzu vedeném Gustávem Husákem a „turdými stalinskými muži“. ${ }^{42}$ Neradostná situace v zemi a počínající normalizace byly vodou na mlýn ostré kritiky nejenom nového režimu v Praze, ale „zločinného komunismu“ jako takového. Týden před prvním výročím „potupné sovětské zrady“ a okupace

39 Jak to bylo v srpnu před deseti lety. Krajanské noviny, č. 16/17, 3. srpna 1978, s. 3.

40 Československo spoutáno imperialismem SSSR. Vídeňské svobodné listy, č. 35-36, 30. srpna 1968, s. 1-2.

41 Jonáš, Josef: Moskva a my. Vídeňské svobodné listy, č. 37, 6. září 1968, s. 1-2.

42 Dubček odstraněn - nástupce Husák - turdý kurs. Vídeňské svobodné listy 24, č. 16, 25. dubna 1969, s. 2. 


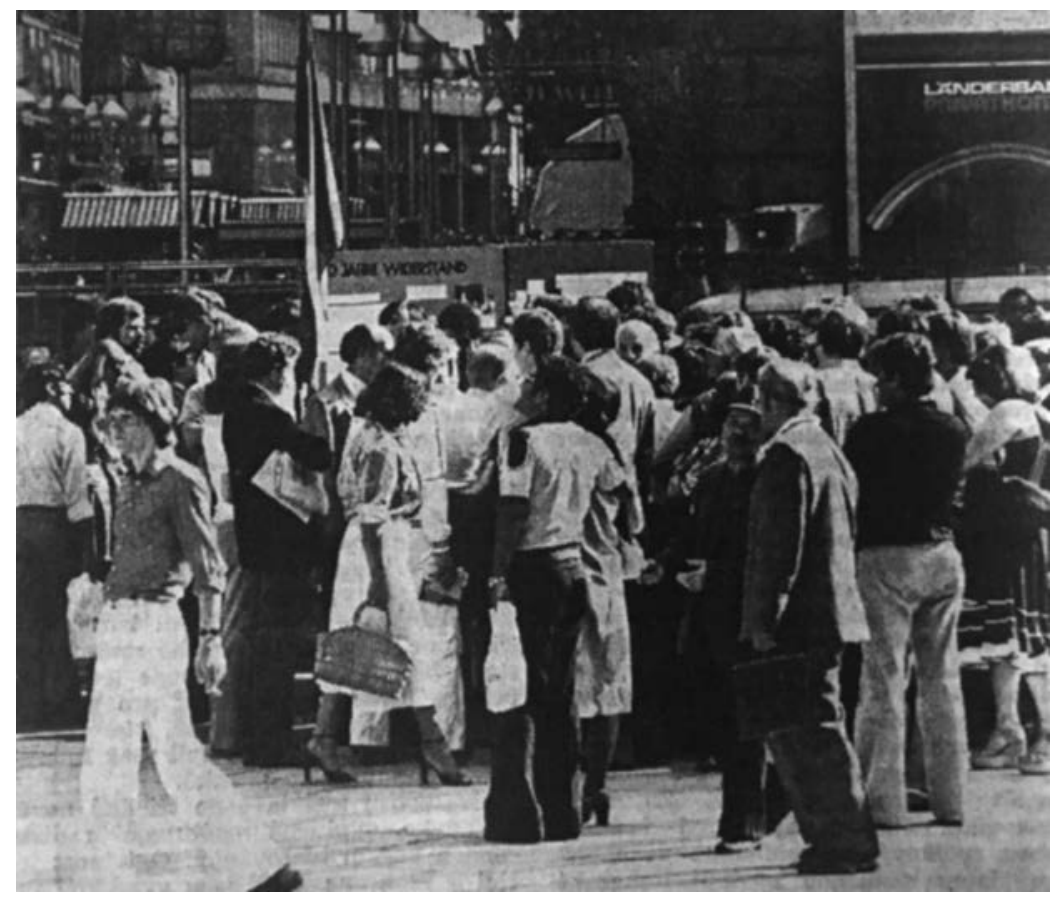

Demonstrace ve Vídni 21. 8. 1977 (Vídeňské svobodné listy, 24. 8. 1978).

Československa otiskly VSL prohlášení Menšinové rady české a slovenské větve v Rakousku, které bylo vydáno v den okupace, a které mělo být platné i rok po ní. V něm odsoudily sovětskou okupaci a zdůraznily, že vytrvají „společněv práci i v boji dokud náš národ nestane opět mezi národy svobodnými - hoden toho, jež z jeho li̊na vzešel: Tomáše G. Masaryka “. ${ }^{43}$ Byl to právě TGM, jehož ideály a myšlenkami se tato část menšiny zaštitovala a jehož si - jako prezidenta osvoboditele - připomínala.

Když došlo k brutálnímu potlačení demonstrací v den prvního výročí, reagovaly VSL v článcích Nikdy se nesmiřr československý lid s potupnou sovětskou okupací! a Bídáci ${ }^{44}$ ostrým odsouzením zásahu a celého pražského komunistického vedení země. Josef Jonáš v článku uvedl, že ve světě: „neprávem oslavované tzv. Pražské jaro musilo skončit tragicky“ a že všechen optimismus části české menšiny a především nových uprchlíků na uchování polednového vývoje byl pouze sebeklamem. 21. srpen 1969 měl všem těmto lidem otevřít oči, protože strana a československá policie opět používají „metody temna“. Čistky ve straně a v různých vrstvách společnosti v následujícím roce byly potvrzením toho, co VSL „tvrdily dávno“ - komunistický režim je nereformovatelný a zločinný.

43 Před rokem zvitězil sovětský imperialismus. Hanba sovětským okupantům - svoboda lidu. Vídeňské svobodné listy 24, č. 32/33, 15. srpna 1969, s. 1.

44 Nikdy se nesmírí československý lid s potupnou sovětskou okupacı? Vídeňské svobodné listy 24, č. 34/35, 29. srpna 1969, s. 1; Bídáci! Vídeňské svobodné listy 24, č. 34/35, 29. srpna 1969, s. 1. 
K 10. výročí invaze vojsk Varšavské smlouvy do Československa se konaly v mnoha západních zemích protestní shromáždění a pietní akce. VSL přinesly na přední straně projev místopředsedy Rakouské socialistické strany a vídeňského starosty Leopolda Gratze, který s odkazem na nedávný pád diktatur v Řecku, Portugalsku a Španělsku vyzval ke „světovému zápasu mezi demokracii a diktaturami, který měl být veden „ofensivně a optimisticky “. V otištěném projevu rovněž poukázal na politiku détente, která podle něj nebyla v protikladu s uvedeným světovým zápasem..$^{45}$ Vedle projevu starosty otiskly noviny prohlášení dalších významných osobností evropské politiky, které se v den výročí vyjádřily k situaci v Československu, jako byli Olaf Palme, západoněmecký ministr zahraničí Hans-Dietrich Gencher nebo sovětský disident Andrej Sacharov. Úvodní straně vévodila fotografie protestního shromáždění převzatá z Arbeiter-Zeitung s komentářem: „Diváci na vídeňském Štěpánském náměstí - za krásného počasi se shromáždilo kolem 200 osob: diváci, kolemjdoucí, turisté, levicovi radikálové a diskutéri z „povoláni“, kteři nikdy nikde nechybi... "46

Redakce novin se nezmiňovala o vlastním pietním shromáždění pořádaném členy Menšinové rady a neuváděla ani jiné menšinové vzpomínkové akce. Přitom na atmosféru ve Vídni a protestní shromáždění vzpomínal signatář Charty 77 Přemysl Janýr, který kvůli perzekuci státních orgánů vycestoval do Rakouska v roce 1978, následovně: „Když jsem príjel do Vidně, [...] to jsem se dostal rovnou těch příprav těch vzpominkových akcí. To byla velice úžasná zkušenost a hlavně člověk okamžitě zapadl do toho velmi rüznorodého prostředí. Protože se na tom tenkrát podílela koalice, která od té doby moc nemá obdoby v Rakousku. To bylo od mladé SPÖ, mladé ÖVP, přes křest’anské kruhy až po maoisty a trockisty. Takže to jsem okamžitě zaplul do rakouského, vídeňského děni. " 47 Je zřejmé, že události roku 1968 spojovaly více rakouskou, než českou menšinovou společnost.

O dalších deset let později byl v úvodním článku 21. srpen 1968 - dvacet let sovětské okupace Československa zveřejněn rozhovor se spisovatelem Heinrichem Böllem, který zažil invazi „na vlastní kůži“ v Praze. K autorově výpovědi byl přiřazen výpočet materiálních ztrát a obětí na životech. Dvacet let zanechalo podle VSL tragické následky a rok 1968 představoval promarněnou jedinečnou př́iležitost, která se otevřela českému a slovenskému národu začátkem toho roku. Na další straně následoval článek Komunisté a jejich proměny 1945/1948 - 1968 - 1988, který přirovnával československé komunisty ke „spolku loupeživých rytírưu. Do tohoto spolku a rovněž „klubu přátel komunistů“ podle redakce spadali i mnozí „údajně pronásledovaní“ uprchlíci, kteří ovšem museli být napůl nemocní, protože „patřili k elitě loupeživých rytírủ a při stranickém turnaji o dosaženi trůnu na hradě českých králů vypadli v roce 1968 ze sedla a [...] po pádu na hlavu trpi ztrátou paméti “. ${ }^{48}$ Terčem této kritiky byli především chartisté, kteří získali v předchozích letech v Rakousku politický azyl poskytnutý Brunem Kreiskym, a mezi kterými byla i část vedoucích osobností pražského jara, především Zdeněk Mlynář nebo Pavel Kohout. Článek následoval

45 Leopold Gratz: okupace varuje. Vídeňské svobodné listy 33, č. 33/34, 24. srpna 1978, s. 1.

46 Tamtéž.

47 Soukromý archiv autora, rozhovor s Přemyslem Janýrem, ml., Vídeň 15. září 2013.

48 Komunisté a jejich proměny 1945/1948 - 1968 - 1988. Vídeňské svobodné listy 43, 24. srpna 1988, č. 31/34, s. 2. 
tím, že „poctivi lidé pak nemohou pochopit, kde tito dobráci berou tolik drzosti mluvit jménem pronásledovaného národa “. 49

Osudný 21. srpen 1968 především utvrzoval členy menšiny sdružené pod Menšinovou radou české a slovenské větve v Rakousku, jejímž hlavním tiskovým orgánem byly právě VSL, o zločinné komunistické moci, která byla podle nich nereformovatelná. Zároveň představovala okupace Československa vojsky Varšavské smlouvy vítanou munici pro kritiku všeho, co bylo v očích tohoto proudu spojeno s komunistickou ideologií - pražského režimu, Sdruženi Čechů a Slováki̊ v Rakousku, některých chartistů nebo posrpnových uprchlíků, kteří byli příliš „deformováni materialistickou výchovou“ nebo dokonce pomáhali zločinný režim sami budovat. Nedá se ovšem tvrdit, že by tato část menšiny vytvořila vzpomínkovou kulturu ve smyslu definovaném manželi Assmannovými. Pokud byl někdo opravdu připomínán, byl to TGM a ideály první republiky, které byly nástupem komunistů k moci soustavně pošlapávány.

\section{Nesmazatelný, ale nepřipomínaný}

Naprosto zlomovou událostí byl 21. srpen 1968 pro ty, kteří byli nuceni opustit z celé řady důvodů tento rok Československo. ${ }^{50}$ Význam pražského jara a především pak způsob jeho potlačení, který vyvolal masivní uprchlickou vlnu, zaujímal přední postavení v jejich životních příbězích, jak doložila řada studií. ${ }^{51} \mathrm{Na}$ tyto nově příchozí čekal ve Vídni, kde se většina z 11000 československých uprchlíků usadila a kde bylo snazší najít odpovídající zaměstnání, nelehký úkol založení nového domova. Integrační proces uprchlíků v hostitelské zemi má řadu úskalí a v prvních fázích jej provázejí úzkostné stavy i deprese. ${ }^{52}$ Řada nově příchozích v Rakousku se je snažila překonat napnutím veškerých sil k budování nové existence, což v praxi znamenalo soustředění se především na ovládnutí jazyka, zisk zaměstnání a odpovídajícího bydlení. ${ }^{53}$ Těmto lidem, kteří zažili komunistickou diktaturu s povinnými průvody a manifestacemi, byly ale cizí spolkové aktivity oslavující československou státnost, prvorepublikové tradice i osobnosti. Udržování českých tradic a účast na menšinových akcích pro ně ztrácela na významu. O tom se v rozhovoru zmiňoval i spisovatel Milan Ráček:

49 Tamtéž.

50 Patřili mezi ně jak čelní představitelé pražského jara, tak i celá řada lékařů, umělců, techniků i pracovníků ve státním sektoru. Více: Mlynář-Dubská, Irena: Integrationsprobleme der Ostblockflüchtlinge in Österreich. Wien 1988, s. 108.

51 Více: Mayer, Vera: Integračni procesy na přikladě etnických menšin ve Vídni. In: Český lid 88, č. 2, Etnologický ústav AV ČR 2001, s. 123-164.

52 Vedle již zmíněných studií Ireny Mlynář-Dubské a Margity Urbanek to byl například i český psychiatr působící v Nizozemí Miroslav Kabela. Srov. Kabela, Miroslav: Vliv emigrace na psychické problémy a choroby českých emigrantů v Nizozemí. In: Emigrace a exil jako zpo̊sob života. II. sympozium o českém vystěhovalectví, exulantství a vztazích zahraničních Čechů k domovu. Edd. S. Brouček, - K. Hrubý - A. Měštan. Praha 2001, s. 32-50.

53 Srov. Urbanek, Margita: Tschechische Flucht, s. 126. 
„Mně osobně ty spolky byly cizi. Ano, ty spolky jako České srdce nebo tak. Ty tradični spolky nacvičovaly nějakou operetu a mèlo to takový hodně nacionálni charakter, a to byla věc, která mě neoslovila. "54

Řada starousedlíků v tomto přístupu, v této snaze o rychlou integraci, viděla zradu české národní věci a ztrátu národního cítění, která měla být zpơsobena neblahým komunistickým vlivem. Přesvědčení, že uprchlíci opustili Československo, jen aby se dostali na zlatý Západ, bylo mezi starousedlíky velmi rozšířené a do jisté míry se shodovalo s propagandou pražského vedení. Slovo emigrant, ztotožněné s emigrací ekonomickou, dostalo pejorativní nádech a bylo spojováno s prototypem kariéristy bez vlasteneckého cítění, jehož jediným cílem bylo rychlé zbohatnutí.

$\mathrm{Z}$ těchto důvodů se posrpnoví uprchlíci rozhodli založit v Rakousku v 70. letech nové vlastní spolky. Nejdůležitějším z nich se stal Kulturni klub Čechů a Slováků v Rakousku, který ve Vídni působí dodnes. Klub, založený 25. října 1974 v malé vídeňské kavárně Falstaff, brzy dosáhl značné prestiže a patřil k nejaktivnějším menšinovým organizacím. ${ }^{55}$ To bylo zpo̊sobeno jednak výraznou osobností spoluzakladatele Přemysla Janýra ${ }^{56}$ a jeho vazbami na čelné představitele rakouské SPÖ (mj. i na spolkového kancléře Bruna Kreiského nebo na Heinze Fischera - pozdějšího rakouského prezidenta), stejně jako aktivitami dalších členů a příznivců Klubu, mezi které patřily takové osobnosti jako Vojtěch Jasný nebo Martin Turnovský. Klub se zaměřil jak na pomoc nově přicházejícím uprchlíkům z Československa (k nimž se řadili od roku 1977 i signatáři Charty 77), tak i na pořádání kulturních akcí, které měly ovšem velmi často politický podtext. At́ již se jednalo o přednášku Anastáze Opaska, autorské čtení Pavla Kohouta nebo hraní Jaroslava Hutky.

Z mnoha aktivit Klubu bylo těch zaměřených na pražské jaro a srpnové události ovšem jen pár. Podle přehledu akcí uspořádaného na základě spolkového bulletinu pro publikaci Vídeňšti Češi 1945-2005 se do roku 1988 uskutečnily pouze dvě akce týkající se roku 1968.57

54 Soukromý archiv autora, rozhovor s Milanem Ráčkem, Sitzendorf / Schmida, 14. září 2011.

55 O vzniku a jednotlivých aktivitách Klubu viz Baslerová, Helena: Kulturni klub Čechů a Slováků v Rakousku. In: Vídeňští Češi 1945-2005. K dějinám národnostní menšiny/ Die Wiener Tschechen 1945-2005. Zur Geschichte einer Volksgruppe. Edd. H. Basler - M. Brandeis - J. Kroupa - J. Starek. Wien - Praha 2006, s. 367-394. Dvěma spolkům - knihovně Jirásek a na počátku sedmdesátých let vzniklému spolku Vlast - se podařilo začlenit jak př́íslušníky „staré menšiny“, tak i uprchlíky z Československa po srpnu 1968. Obě organizace se zaměřily především na pomoc nově příchozím po srpnu 1968. Více o založení spolku Vlast viz: Starek, Jana: Česká menšina, s. 308.

56 Přemysl Janýr byl jeden z předních sociálních demokratů, který se během pražského jara stal členem přípravného výboru na obnovu Československé sociální demokracie a od října 1968 pobýval v exilu ve Vídni. Zde se spojil s rakouskou sociální demokracií (SPÖ) a měl dobré kontakty na její špičky včetně pozdějšího rakouského kancléře Bruna Kreiského. Především funkcionáře stran nacházející se v zahraničí považovala StB za mimořádně důležité (a nebezpečné) a věnovala jim proto značnou pozornost. Jak vypovídá svazek DEMOKRAT, který obsahuje stovky stran, byl Přemysl Janýr od počátku svého pobytu v Rakousku neustále sledován, a to až do samého konce komunistického režimu v Československu. Srov. Archiv bezpečnostních složek v Praze, f. Svazková agenda hlavní správy rozvědky, objektové svazky, reg. č. 12613/320, sv. Demokrat.

57 Jednalo se o vzpomínání Leopolda Grünwalda, který vystoupil v roce 1968 proti okupaci ČSSR a byl za to vyloučen z KPÖ nazvané: Doba se mění a my se měníme s ní. Druhou byl kulatý stůl k výročím 1938, 1948 a 1968, kterého se zúčastnili Erazim Kohák, Radomír Luža, Přemysl Janýr, Zdenek Mlynář a Ivan Medek. Srov. Basler, H.: Kulturni klub, s. 386. 
Až ke dvacátému výročí okupace Československa vojsky Varšavské smlouvy se uskutečnila celá řada vzpomínkových akcí pořádaných především Rakouským výborem solidarity s $\check{C C S S R}^{58}$ na něž Kulturni klub zval. Pravděpodobně největším podnikem, který Kulturni klub spolupořádal, byl diskuzní seminář: Pražské jaro po dvaceti letech, kterého se zúčastnili nejen čeští, ale i rakouští intelektuálové a pamětníci včetně vídeňského místostarosty Erharda Buska nebo bývalého předsedy Svazu čs. spisovatelů Eduarda Goldstückera.

Ač tedy 21. srpen 1968 ovlivnil naprosto zásadním způsobem životy posrpnových uprchlíků, vzpomínkových akcí nebylo mnoho a ty nejvýraznější se konaly ve spolupráci s rakouskými partnery. Jednou z možných odpovědí na otázku, proč se 21. srpen neproměnil v připomínané datum posrpnových exulantů v Rakousku se specifickou vzpomínkovou kulturou, může být právě složitá situace samotné české menšiny v Rakousku. Ta byla rozdělená a znesvářená a přední činitelé pražského jara se stejně jako mnozí posrpnoví uprchlíci často stávali předmětem kritiky a odsouzení. Proto se nově příchozí raději snažili o rychlou integraci (někteří autoři mluví o asimilaci) ${ }^{59} \mathrm{a}$ na traumatizující příchod sovětských tanků, který jim změnil natrvalo život, se snažili spíše zapomenout.

Zajímavých dokladem vzájemného nepochopení se stala jiná vzpomínková akce Klubu s mezinárodním ohlasem: slavnostní odhalení pamětní desky Tomáše G. Masaryka, které uskutečnil spolkový kanclér Bruno Kreisky 13. září 1982. Byla na něm př́ítomna řada významných osobností rakouského veřejného života. ${ }^{60} \mathrm{~V}$ kontrastu s účastí předních rakouských politiků byla zarážející reakce zástupců českých menšinových spolků, kteřî shodně pozvání odmítli a akce se nezúčastnili. Dokonce se o této, pro českou menšinu jistě důležité události, ani nezmínili (až na jedno nekomentované sdělení ve Vídeňských svobodných listech převzaté z Wiener Zeitung) ${ }^{61} \mathrm{v}$ menšinovém tisku. Pro většinu členů „staré“ české menšiny byl přitom Masaryk obdivovaným ztělesněním ideálů samostatného státu. Jejich nepř́ítomnost však představovala jasné sdělení posrpnovým exilovým skupinám. Tato neúčast byla nejen tichým vyjádřením nesouhlasu s aktivitami Klubu, ale také důkazem, jak hluboký př́íkop nedůvěry mezi starousedlíky odvolávajícími se na tradice první republiky a nově příchozími existoval.

\section{1. srpen a Češi ve Švýcarsku}

Odlišná situace panovala v české komunitě ve Švýcarsku. Místní krajanské hnutí, na jehož chodu se aktivně podílelo v celém Švýcarsku jen něco málo přes 100 osob, jejichž

58 Rakouský výbor solidarity s ČSSR (něm. Österreichische ČSSR-Solidaritätkomitee) byla nadstranická organizace založená vědeckým publicistou Georgem Breuerem, která organizovala kromě vzpomínkových akcí především pomoc a podporu pronásledovaným československým disidentům. Více: Starek, J: Česká menšina, s. 314.

59 Brousek, Karl: Wien und seine Tschechen. Integration und Assimilation einer Minderheit im 20. Jahrhundert. Wien 1980.

60 Nechyběl mezi nimi Heinz Fischer, v té době předseda poslaneckého klubu SPÖ, nebo Herta Firnberg, rakouská ministryně pro vědu a umění.

61 Vídeňské svobodné listy, č. 37/38, 16. září 1982, s. 2. 
věkový průměr byl navíc nad 60 let, koncem 60. let pozvolna zanikalo. Příčinou tohoto stavu byla přísná imigrační politika Švýcarského spříseženství, které i po únorovém převratu v Československu poskytlo politický azyl jen minimálnímu počtu Čechoslováků (respektive jej udělilo pouze 16 osobám z 66 žádostí). ${ }^{62}$ Vlivem malé členské základny a jejímu vysokému věku zanikly i dva prorežimní spolky, a české krajanské hnutí tak bylo oproti rakouskému jednotné. ${ }^{63}$ Krajanské spolky byly sdruženy ve Svazu československých spolkư ve Švýcarsku a jejich členové se také okamžitě s tím, jak dorazily do Švýcarska první zprávy o invazi, zapojili do pomoci přicházejícím uprchlíkům. Jejich příliv byl tak mohutný, že nejenom přinesl novou krev a omlazení dožívajícím krajanským spolkům, ale slovy historika Skoupého doslova přeměnil celou komunitu na „hnutí posrpnového exilu“. ${ }^{64}$ Švýcarsko totiž poskytlo v letech 1968-1970 právní ochranu a podporu 11973 uprchlíkům z Československa, což byl v té době největší počet udělených politických azylů československým občanům ze všech zemí demokratického Západu.

Podle některých autorů zachvátila švýcarskou společnost doslova všeobecná československá euforie. ${ }^{65}$ Atmosféru bezpodmínečného přijetí, kterou zažívali během příjezdu do Švýcarska, popisovala většina autorem oslovených narátorů a zmiňovaly ji rovněž studie zabývající se integrací československých uprchlíků tématizují tuto nebývale silnou vlnu solidarity. ${ }^{66}$ Švýcarská společnost, která sledovala dění v okupované zemi se zaujetím, se identifikovala s osudem malé středoevropské země, jejíž občané se navzdory sovětským jednotkám v ulicích zoufale a nenásilně snažili o zachování nezávislosti a udržení na jaře 1968 započatých reforem. Záběry tanků obklopených davy Čechů a Slováků požadujících po přítomných vojácích vysvětlení jejich př́ijezdu, nenásilný odpor i mnohatisícové demonstrace, našly ve švýcarské společnosti značnou odezvu.

At již byl příčinou stav krajanského hnutí před srpnem 1968 nebo často v rozhovorech zmiňovaná pomoc uprchlíkům v počátcích integrace, výsledkem bylo, že rozpory mezi skupinami starousedlíků a nově příchozími byly v porovnání s českou menšinou v Rakousku minimální. I když narátoři popisovali jistý odstup původních krajanů, nikdy se nejednalo o překážky bránící ve vzájemné spolupráci. Švýcarské orgány se navíc snažily rozmístovat československé uprchlíky rovnoměrně, aby příliš nezatížily úřady jednoho kantonu a zabránily vzniku velkých českých a slovenských komunit. Oproti Rakousku, kde byla hlavním centrem posrpnového exilu Vídeň, začaly počátkem 70. let vznikat nové spolky po celém Švýcarsku. ${ }^{67}$

62 Srov. Banki, Ch. - Späti, Ch.: Ungaren, Tibeter, Tschechen und Slowaken, s. 390.

63 Srov. Trapl, Miloš - Skoupý, Arnošt - Kouřil, Miloš: Československý exil a krajanská hnuti ve Šuýcarsku v letech 1945-1989. Od května 1945 do srpna 1968. Olomouc 2004.

64 Skoupý, Arnošt: Svaz československých spolků ve Švýcarsku v proním roce příchodu naši posrpnové emigrace. In: Emigrace. Sborník historických prací Centra pro československá exilová studia. Edd. K. Konečný - T. Motlíček. Olomouc 2006, s. 26.

65 Banki, Ch. - Späti, Ch.: Ungaren, Tibeter, Tschechen und Slowaken, s. 398.

66 Rendl, Renate: Die Integration der politischen Flüchtlinge aus der Tschechoslowakei in der Schweiz seit 1968. In: Asyl und Aufenthalt: die Schweiz als Zuflucht und Wirkungsstätte von Slaven im 19. und 20. Jahrhundert. Edd. M. Bankowski. Basel/ Frankfurt am Main 1994, s. 239-253; Banki, Ch. - Späti, Ch.: Ungaren, Tibeter, Tschechen und Slowaken, s. 369-415.

67 Vedle nových sokolských jednot vznikaly ve Švýcarsku i další významné spolky nejrůznějšího zaměření. 
Rovněž hlavní tiskový orgán Svazu čs. spolků nazvaný Zpravodaj vznikl z potřeb posrpnových uprchlíků. Ve snaze předat všechny potřebné informace co největšímu množství nově příchozích, se Svaz rozhodl pravidelně vydávat informační bulletin, který se záhy stal nejdůležitějším periodikem českých krajanů ve Švýcarsku. První číslo vyšlo díky velkému nasazení členů Svazu již 9. září $1968{ }^{68}$ Vydání obsahovalo jak seznam existujících československých spolků se jmény a kontaktními údaji jejich předsedů, na které se mohli Češi a Slováci obrátit, tak i důležitá sdělení úřadů a pomocných organizací nebo pozvání na chystané akce krajanské komunity. ${ }^{69} \mathrm{~V}$ podobném duchu se nesla i další čísla, ve kterých nechyběly informace o švýcarském sociálním pojištění, daních v jednotlivých kantonech, pracovních nabídkách u soukromých firem i o průměrných platech v jednotlivých průmyslových odvětvích. Součástí rubriky věnované reakcím čtenářủ byla dokonce i seznamka. ${ }^{70}$ Zpravodaj se stal cenným zdrojem informací, což mi po letech potvrdila v rozhovoru i řada narátorů. ${ }^{71}$

\section{Mezník vzpomínaný}

Nejvíce se tzv. vzpomínková kultura, jejímž středobodem byl rok 1968, rozvinula právě u českých krajanů ve Švýcarsku. Byli to českoslovenští uprchlíci, kteří doslova zachránili tamní českou komunitu před postupným zánikem a přeměnili ji ve své vlastní hnutí. 21. srpen 1968 se nejen mnohokrát objevuje jako hlavní téma Zpravodaje, ale zároveň je předmětem řady setkání, přednášek a sympozií. Jedná se o mezník, který českou krajanskou obec $\mathrm{v}$ mnoha ohledech definoval a dodnes definuje, a byla mu proto věnována odpovídající pozornost i ve Zpravodaji. Přední stránce čísla vydanému k prvnímu výročí sovětské okupace ČSSR dominuje ironická fotografie sovětské protivzdušné obrany instalované před domem v centru Prahy, který zve na výstavu sovětského umění 20. let. Celé číslo bylo věnováno vzpomínkám očitých svědků, výňatku dokumentace Historického ústavu ČSAV, tzv. Černé knize, článkům, které vyšly v osudový den v Československu nebo karikaturám z časopisu Dikobraz. V rubrice Bilance a perspektivy je hlavní článek: K pronimu výroči druhého protektorátu, který objasňuje důvody pražského jara a popisuje neradostnou realitu počínající normalizace. ${ }^{72}$

At již šlo o odborovou činnost (Československý svaz křestanských pracujicich) nebo o duchovní službu (Česká katolická misie ve Švýcarsku či Pitterưv Husưv sbor). V roce 2000 uváděl Arnošt Skoupý existenci 23 spolků, z čehož 20 jich bylo sdruženo ve Svazu českých a slovenských spolků ve Švýcarsku a pouze tři vyvíjely činnost mimo něj. Srov. Skoupý, Arnošt: Krajanské spolky jako zpi̊sob adaptace. Některé poznatky ze studia historie krajanských spolků ve Švýcarsku. In: Češi za hranicemi na přelomu 20. a 21. století. Sympozium o českém vystěhovalectví, exulantství a vztazích Čechů k domovu 29-30. června 1998. Edd. K. Hrubý - S. Brouček. Praha 2000, s. 110.

68 Jmenovitě Miroslavu Tučkovi a předsedkyni Svazu spolků Štěpánce Čermákové. Tamtéž, s. 26.

69 Více o vzniku časopisu: Čermáková, Štěpánka: Úvodem. In: Archiv Centra pro československá exilová studia, fond Exilová periodika a publikace, Zpravodaj 1/1, Curych 9. záŕí 1968.

70 Zpravodaj 1-14, 1968.

71 Např́klad: Soukromý archiv autora, rozhovor s Danou Linhartovou, Blansko 17. dubna 2013.

72 Porges, Antonín: K pronímu výročí druhého protektorátu. In: Zpravodaj 2, č. 11-12, Curych 1969, s. 9-11. 


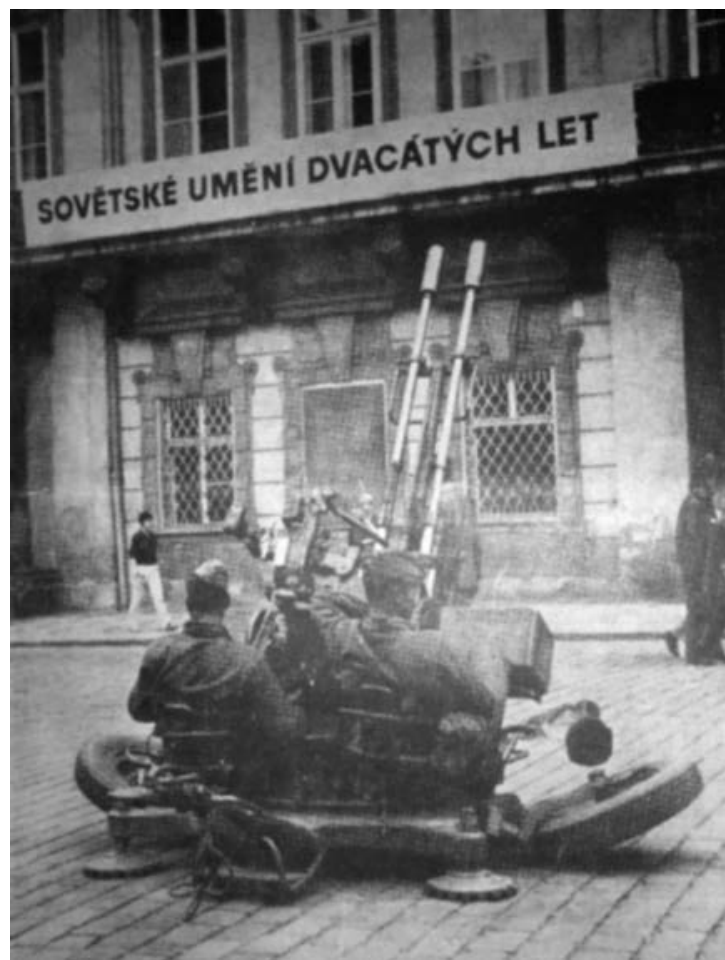

Přední strana časopisu Zpravodaj (roč. 2, č. 11-12).

Zpravodaj rovněž informoval o řadě vzpomínkových akcí, které se ve Švýcarsku uskutečnily k příležitosti prvního výročí. Jednalo se například o manifestační shromáždění svolané Svazem čs. spolků na Bürlingplatz v Curychu, během kterého byla přečtena dvě memoranda (Poděkováni švýcarské vládě a Poselstvi lidu Československa) a kterého se zúčastnila i řada Švýcarů. V Basileji zase zorganizoval spolek Domov tzv. Pochod mlčení, během kterého byl na hlavní ulici položen věnec k soše sv. Jakuba a zazpívána československá hymna. ${ }^{73}$

I číslo Zpravodaje, jehož vydání připadlo na desáté výročí okupace, nenechalo už od pohledu nikoho na pochybách, jaké události bylo z velké části věnováno. Přední straně vévodila velká dobová fotografie z 21. srpna 1968 z centra Prahy, na které protestují dva studenti s československou vlajkou v ruce. O významu tohoto výročí a důležitosti, kterou mu česká a slovenská komunita ve Švýcarsku připisovala, svědčila i výzva Svazu čs. spolků všem krajanům otištěná na první straně. Jednalo se o pobídnutí členů k finanční podpoře vzpomínkových akcí chystaných na druhé pololetí roku, z nichž nejdůležitější byly oslavy spojené se vznikem Československa a rovněž s obsazením ČSSR vojsky Varšavské smlouvy. K této prŕležitosti byla 19. srpna 1978 odhalena pamětní deska na Münsterhofu v Curychu a v den výročí manifestace uspořádán komorní koncert v Basileji, kterého se 
zúčastnili nejen Češi a Slováci, ale i jejich švýcarští přátelé. Připomínané datum mělo totiž silný náboj pro sebeidentifikaci švýcarské společnosti, která si prostřednictvím pomoci československým uprchlíkům nenásilně bojujících proti útlaku potvrzovala správnost svých demokratických tradic. Z tohoto pohledu bylo 10 . výročí okupace důležité i pro švýcarskou společnost a připomínkových akcí se tak zúčastnilo i nemálo Švýcarů, kteří se zapojili o 10 let dříve do pomoci nově příchozím. Skutečnost, že se postoj švýcarské vlády v roce 1968 ř́dil kromě humanitárních rovněž ekonomickými hledisky, ${ }^{74}$ nehrál pro vzpomínkovou kulturu, která se k srpnovým událostem vázala, žádnou roli.

Výše zmíněné číslo Zpravodaje z roku 1978 rovněž obsahovalo několik úvah, článků a analýz věnujících se osudovým dnům, přičemž nejvíce prostoru získal příspěvek $O s m$ měsicu jednoho jara českého historika Milana Haunera žijícího od roku 1968 v exilu ve Velké Británii. Jednalo se o detailní rozbor pražského jara a jeho následného potlačení, který vycházel na pokračování i v dalších číslech časopisu. ${ }^{75}$ Spolu s ním zahrnovalo číslo i několik stran fotografií zachycujících dramatické scény z invaze vojsk Varšavské smlouvy a rubriku Smích v slzách plnou hořce ironických karikatur vztahujících se rovněž k okupaci ČSSR. V čísle se také objevily informace o probíhající podpisové akci Petice 78 nebo o vzpomínkové výstavě, která proběhla v galerii Ra Riedt, níž bylo vystavováno exilové umění československých umělců „ze všech světadílůđ, jak tvrdila pozvánka. ${ }^{76}$ Připomínkových akcí proběhla ten rok celá řada a i ostatní čísla Zpravodaje téma pražského jara a následné okupace dále rozvíjela. ${ }^{77}$

Nejinak tomu bylo o 10 let později při př́ležitosti 20. výročí Srpna. Redakce Zpravodaje se rozhodla na titulní stranu umístit obrázek dárkově zabaleného tanku s podtitulem: 20. výroč okupace ve znameni perestrojky. Celé číslo opět opanoval rok 1968 a s ním spojené vzpomínkové akce. Největší z nich nazvaná Nezapomínáme... Československo 1968 se konala od pátku 19. do 21. srpna 1988 v Curychy v budově místního Kongresshausu. Sobotního večerního programu, který zahrnoval koncert orchestru Dunaj, vystoupení taneční skupiny Folklor 75 a projev Františka Schwarzenberga, se zúčastnilo podle odhadů redaktora 800-1000 diváků. Po programu následoval pochod k pamětní desce na Münsterhofu, kde promluvil curyšský starosta Thomas Wagner. Patronát nad akcí převzali mj. Rafael Kubelík, Tomáš Bata nebo spoluzakladatel slovenské Demokratické strany Martin Kvetko. Pozvána byla i řada zahraničních hostů. Svaz čs. spolků ve Švýcarsku zval krajany na akci těmito slovy: "Je samozřejmou národni povinnosti každého, komu byl udèlen ve Švýcarsku azyl (a mnohým i statni občanství), aby účasti na této manifestaci projevili dik za porozumění, kterého se našim uprchliki̊m dostalo a zároveň dokumentoval svou věrnost demokracii a jejím ideáliom. "78 Vzpomínkové akce, které se rovněž konaly v Bernu a dalších

74 Například švýcarské noviny Der Schweizerische Beobachter v prosinci 1968 poukazovaly na fakt, že vládě ve skutečnosti jde v př́ípadě Čechů a Slováků jen o levnou pracovní sílu pro švýcarské firmy a dodávaly: „privilegované zacházení s novými uprchlíky proto nezná žádných hranic." In: Banki, Ch. - Späti, Ch.: Ungaren, Tibeter, Tschechen und Slowaken, s. 402.

75 Hauner, Milan: Osm měsícú jednoho jara. In: Zpravodaj 11, č. 7-8, Curych 1978, s. 17-20.

76 Vzpomínková výstava. In: Zpravodaj 11, č. 7-8, Curych 1978, s. 37.

77 Např́íklad: Hauner, Milan: Zář́ 38 a srpen 68: Paralely? In: Zpravodaj 11, č. 9, Curych 1978, s. 1-2.

78 Výzva krajanské veřejnosti. In: Zpravodaj 21, č. 7-8, Curych 1988, s. 1. 
městech, byly dokladem významu Srpna pro celou krajanskou komunitu. Ve Zpravodaji byly otištěny vzpomínky Josefa Škvoreckého i Václava Havla, báseň Karla Kryla a byla zde uveřejněna i obsáhlá reportáž o tehdejších protestech v Praze.

Zajímavostí byl i dopis zástupců Svazu čs. spolku adresovaný prezidentu Reaganovi, který jej vyzýval k projednání stažení sovětských vojsk z ČSSR na připravovaném jednání s Michailem Gorbačovem. V dopise zástupci argumentovali právě srpnovou okupací: „[...] v roce 1948 došlo v Československé republice s pomoci sovětských diplomatů a agentů $k$ nastoleni komunistického teroru a dne 21. srpna 1968 k př́mé okupaci naši vlasti sovètskou armádou. Tuto okupaci, která trvá již téměř plných 20 roki̊, pocitujeme my, Češi a Slováci jako historickou nespravedlnost. “ Dopis končil těmito slovy: „Za Vaši činnost v této spravedlivé věci Vám srdečně děkujeme a věřme, že skonči stejným úspěchem, jako v Afganistánu. "79 $\mathrm{O}$ tom, že pro krajany ve Švýcarsku byl Srpen stále živý, měl být vyrozuměn i prezident Spojených států.

Vedle Zpravodaje potvrdily i prameny uložené v archivech jednotlivých spolků, ${ }^{80}$ jak významnou roli hrálo datum 21. srpna 1968 v celém krajanském hnutí. Bylo to násilné potlačení pražského jara, které nejen vyvolalo obrovskou vlnu solidarity ve švýcarské společnosti, ale také naprosto zásadně obměnilo strukturu krajanského hnutí, v němž posrpnoví uprchlíci bud' vytvořili nové spolky, anebo výrazně posílili a omladili ty stávající. Okupace ČSSR i následná švýcarská pomoc proto představovaly jedny ze zásadních životních momentů nejen pamětníků, se kterými jsem vedl rozhovory v rámci terénního výzkumu, ${ }^{81}$ ale i těch, jejichž výpovědi byly zachyceny v odborné literatuře ${ }^{82}$ Srpen a švýcarská solidarita se staly zásadními úhelnými kameny krajanské identity a množství i rozsah vzpomínkových akcí toho byly dokladem.

\section{Závěr}

V dějinách existují události, okolo kterých se díky jejich důležitosti pro danou skupinu brzy vytvoří vzpomínková kultura, a tyto mezníky pak bývají připomínány nejrůznější formou. Na druhou stranu mají zůstat některé z nich zapomenuté, popřípadě jsou „usilovně zapomínané“. Pro české exilové skupiny platily v případě 21. srpna 1968 obě varianty. Pro prorežimní část české menšiny v Rakousku představovalo pražské jaro a následná invaze v duchu normalizace pomoc armád spřátelených států proti kontrarevoluci, která byla zmiňována jen v nejnutnějších případech. Pro její protirežimní část byl naproti tomu Srpen důkazem zločinnosti komunistického režimu v Praze i Moskvě a jeho připomínání sloužilo jako nástroj pro řadu ostrých polemik. Nicméně k rozvinutí specifické vzpomínkové kultury nedošlo, což platí překvapivě i pro posrpnové uprchlíky, jejichž hlavním spolkem byl Kulturní klub Čechů a Slováků v Rakousku. Ti vzpomínkových akcí k uvedenému datu, soudě dle časopisu Klub, upořádali za 20 let pouze několik. Důvodem mohla

79 Dopis prezidentu R. Reaganovi. In: Zpravodaj 21, č. 7-8, Curych 1988, s. 34.

80 Archiv Besedy Svatopluka Čecha v Curychu. Almanach 1910 - 2010, s. 2; Archiv Besedy Slovan v Ženevě. Přehled významnějších akcí, s. 1-58.

81 Např.: Soukromý archiv autora, rozhovor s Karlem Kukalem, Bern, Švýcarsko 25. října 2013.

82 Šimko, Dušan: Exil in Basel. Gespräche mit Flüchtlingen aus der Tschechoslowakei. Košice 2003. 
být právě ona roztříštěnost české menšiny, která vedla mnohé bývalé uprchlíky ke snaze se co nejdříve integrovat do rakouské společnosti a nepř́ijemnou minulost zapomenout.

Zásadně odlišné to bylo v případě krajanského hnutí ve Švýcarsku, které bylo obrovským př́livem československých uprchlíků nebývale posíleno. A to do té míry, že někteří autoři hovoří o transformaci tamní komunity ve hnutí posrpnového exilu. Nově příchozí se setkali ve Švýcarsku s nebývalým přijetím. Právě solidarita švýcarské společnosti spolu s faktem, že naprostá většina Čechů ve Švýcarsku př̀šla do země v rámci posrpnové exilové vlny, vytvořila podmínky pro rozvoj silné vzpomínkové kultury. Ta je zmiňována nejen v celo-krajanském časopise Zpravodaj, v různých vyjádřeních pamětníků, ale i v pramenech jednotlivých spolků. Srpen 1968 tak stál v základech nové krajanské identity - a byl z toho důvodu důsledně připomínán. To, že bude připomínán od roku 2021 v České republice jako Památný den obětí invaze a následné okupace vojsky Varšavské smlouvy, vypovídá mnohé o změně, kterou prodělala od roku 1989 i samotná česká společnost.

\section{Recalling August 1968: Significance of the year 1968 for the Czech Exile in Austria and Switzerland}

The year 1968 is undoubtedly a milestone in the Czech and Slovak history. However, until the Velvet Revolution in 1989, the occupation of the former Czechoslovakia by troops of the Warsaw Pact had been labelled as a fraternal help of the befriended socialist states. The events of that year caused deep and long lasting changes in Czechoslovakian policy and influenced the Czech exile communities. The main research question of the paper is what role August 21, 1968 played for the Czech exile. Was there any exile group which created the so called remembrance culture centralized on that date? This study deals with the Czech communities in Austria and Switzerland after 1968 and remembrance culture of their members. The content analysis of the periodical press and recorded interviews with members of the Czech exile discovered profound differences in their approach to August 21. That was especially obvious in case of the Czech minority in Austria which had been split into various antagonised groups until 1994. There were pro-governmental exile parties which followed the official stance of the Czechoslovakian (and Soviet) government. The date and the event was a milestone, however, a milestone which they tried to avoid mentioning, which they tried to forget. On the other hand, there existed exile groups which used the milestone as a tool for instant criticism of the governments in Czechoslovakia or Soviet Union. The date was instrumentalized but there was no development of remembrance culture as such. The situation was different in Switzerland. Due to the benevolent immigration policy of the Swiss Confederation, the local Czech communities - which were literally dying out - were completely transformed by the incoming refugees. It was Swiss solidarity with the newcomers and the fact that the most of them arrived in the country after August 21, 1968 which were the cornerstones of the remembrance culture and fundaments of the new compatriot identity. 
